\title{
Temporal fluctuations of zooplankton and bacteria in the middle Adriatic Sea
}

\author{
A. Baranović, M. Šolić, T. Vučetić, N. Krstulović \\ Institute of Oceanography and Fisheries, POB 500, 58000 Split, Croatia
}

\begin{abstract}
Year-to-year fluctuations in the abundance of zooplankton (1960-1982) and bacteria (1968-1988) were examined. Three main patterns of year-to-year changes in abundance were extracted by Principal Component Analysis (PCA): (1) Cyclical oscillations with 5.5 yr periodicity. This pattern is well correlated with salinity and southerly weather type (lower atmospheric pressure, southeasterly wind and higher precipitation) and can be accounted for by the water exchange between the Mediterranean and the Adriatic Sea. (2) Long-term trend of increasing abundance presumably due to the open Adriatic eutrophication. (3) Oscillations with $7.3 \mathrm{yr}$ periodicity. This pattern is well correlated with temperature
\end{abstract}

\section{INTRODUCTION}

A number of abiotic and biotic parameters have been studied in the middle Adriatic over the last 45 yr. Basic hydrographic parameters have been followed ever since 1948 and a number of chemical and biological parameters have subsequently been included. Fluctuations of different climatic and hydrographic parameters affecting the production of this area have also been studied (Buljan \& Zore-Armanda 1966, 1979, Buljan 1969). Long-term fluctuations of phytoplankton and primary production (Pucher-Petković 1963, 1966, 1971), zooplankton (Vučetić 1971a, b, 1988), bacteria (Krstulović \& Šolić 1990, Šolić \& Krstulović 1991a, b) and commercially important pelagic fish (Županović 1968, Karlovac 1973, Regner \& Gačić 1974) have been analyzed. Parallel observations of these fluctuations pointed to the fact that they were interrelated and contributed to the characterization of dynamic processes in the Adriatic ecosystem (Pucher-Petković 1968, Vučetić 1973, 1975, 1977, Karlovac et al. 1974, Šolić \& Krstulović 1991a, b).

Zooplankton fluctuations have been observed since 1957. The typical annual curve, showing seasonal anomalies, of standing crop for the coastal, channel and open sea regions was obtained from dry weight data for 1959-1970 (Vučetić 1971a). The long-term fluctuations of standing zooplankton crop were dis- cussed in connection with variations in predator abundance (Vučetić 1971b, 1973).

Bacterial fluctuations have been studied since 1968. High correlation between bacteria and phytoplankton fluctuations have been reported (Krstulović 1989, Šolić \& Krstulovic 1991a). The effects of eutrophication on the long-term fluctuations of bacteria have also been studied (Krstulović \& Šolić 1990).

In this study, long-term fluctuations of some important zooplankton groups and heterotrophic bacteria were analyzed. Multivariate methods were used to extract the main patterns of year-to-year changes in abundance and to discriminate between years. The interactions between zooplankton fluctuations and those of bacteria and various environmental factors were given particular attention.

\section{MATERIALS AND METHODS}

Data collection. Data on zooplankton and heterotrophic bacteria abundance were obtained from monthly sampling during 1960-1982 and 1968-1988 respectively. Sampling was performed at a station located southeast of Cape Stončica on Vis Island $\left(43^{\circ} 00^{\prime} \mathrm{N}, 16^{\circ} 20^{\prime} \mathrm{E}\right)$, about $100 \mathrm{~m}$ deep and about $50 \mathrm{~km}$ offshore. The station is typical of the open middle Adriatic. The same sampling methods and analyses were applied throughout the study period 

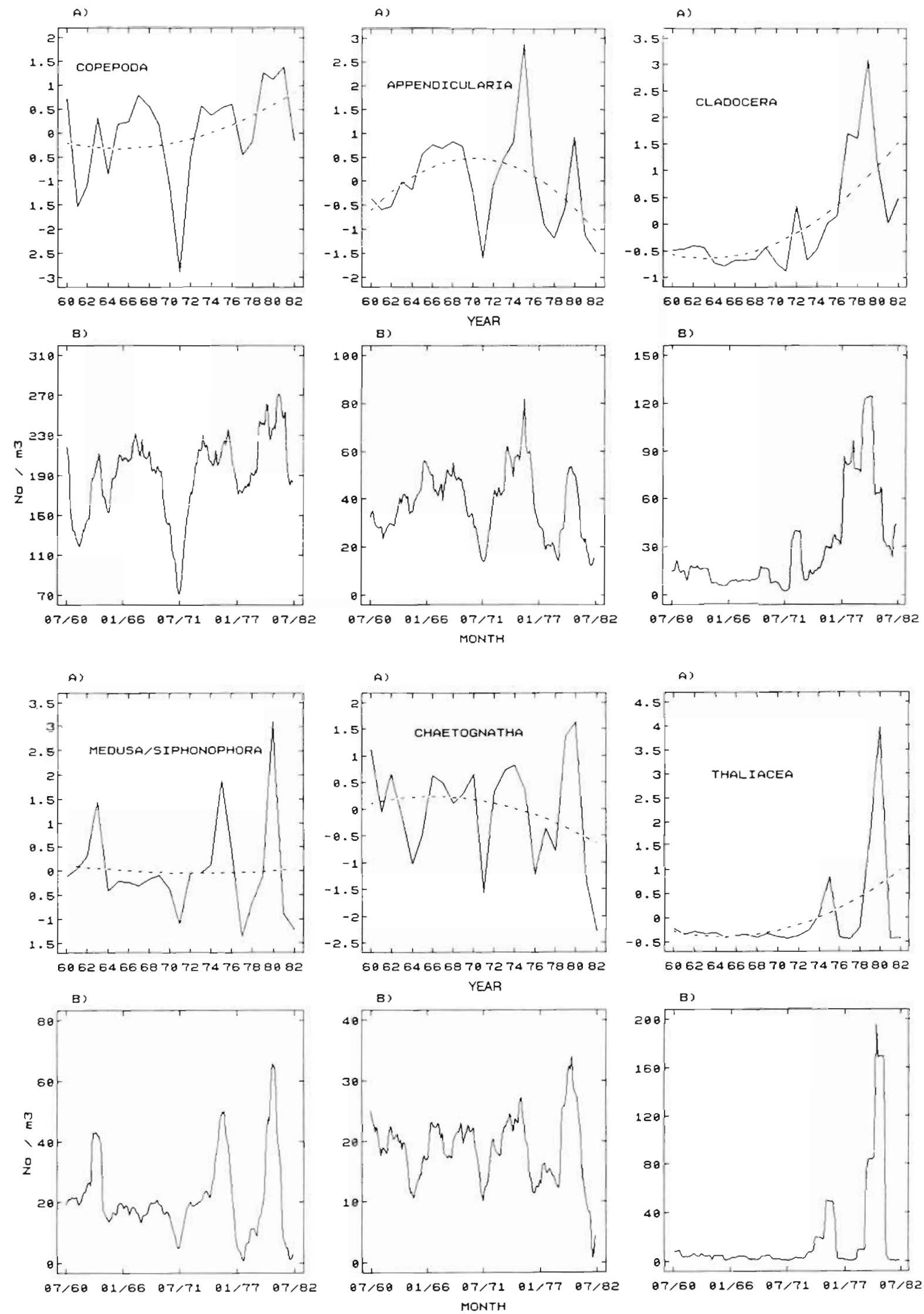
A)

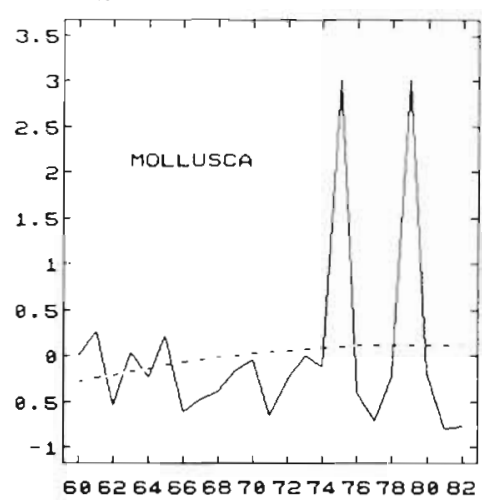

8)

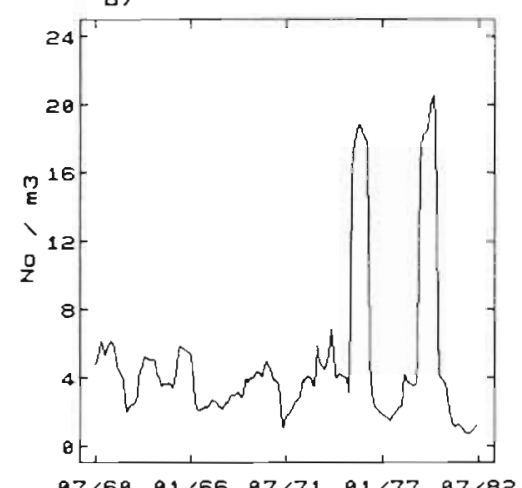

$07 / 68 \quad 01 / 66 \quad 07 / 71 \quad 01 / 77 \quad 07 / 82$

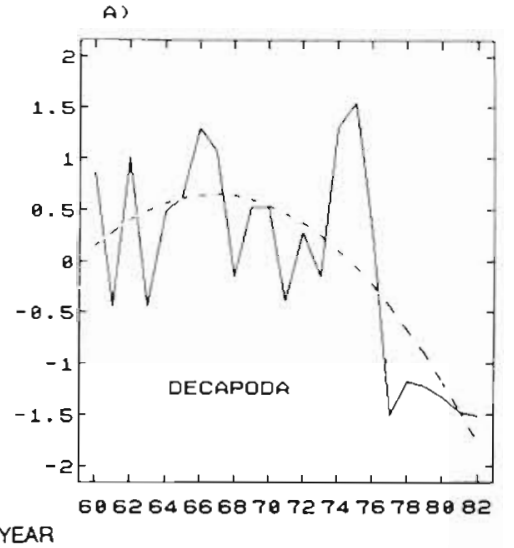
YEAR

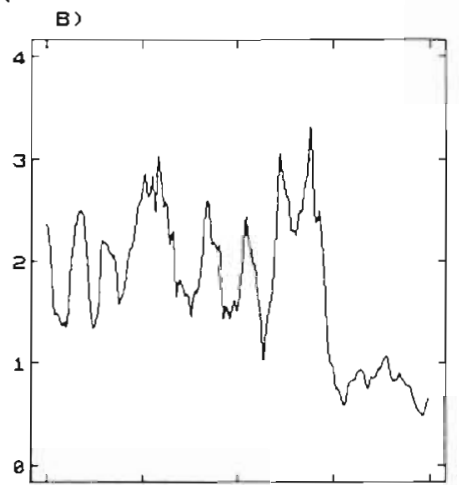

$07 / 60 \quad 01 / 66 \quad 07 / 71 \quad 01 / 77 \quad 07 / 82$

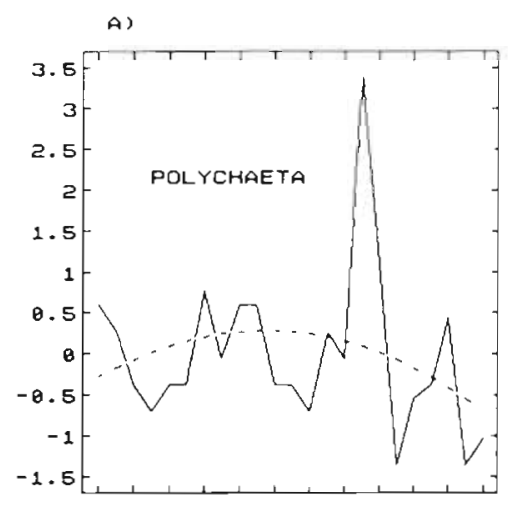

686264666879727476788882

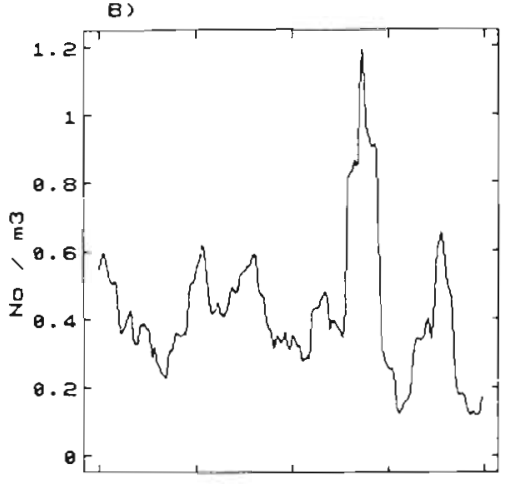

$\begin{array}{llllll}07 / 68 & 01 / 66 & 07 / 71 & 01 / 77 & 07 / 82\end{array}$

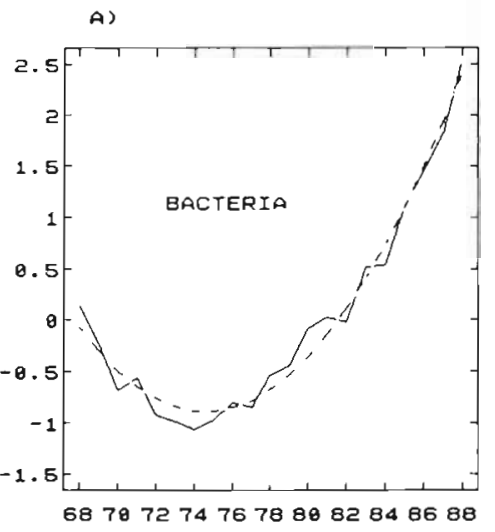
YEAR

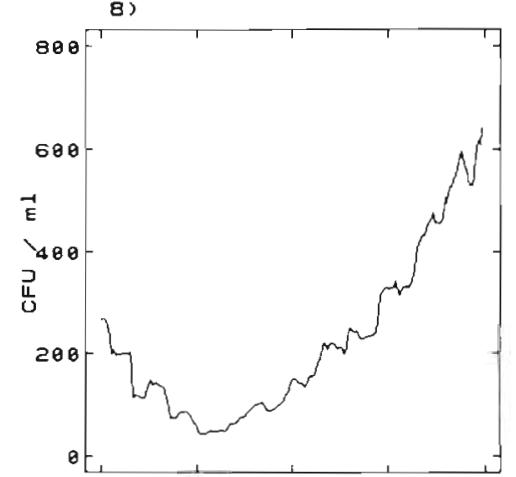

$\begin{array}{lllll}07 / 68 & 87 / 73 \quad 07 / 78 & 07 / 83 & 07 / 88\end{array}$ MONTH
Zooplankton: Zooplankton samples were taken with a Hensen plankton net of $73 \mathrm{~cm}$ mouth aperture. A silk (No. 3) net part of $130 \mathrm{~cm}$ length is attached to a linen part which does not filter sea water. The net was hauled vertically from bottom to surface at $0.3 \mathrm{~m} \mathrm{~s}^{1}$ Collected material was preserved in $2 \%$ formaldehyde. Better represented groups were partially counted $(1 / 20$ of the catch) and poorer represented ones were analyzed as a composite sample. Only counts of adults were utilized. Density is expressed as no. of ind. $\mathrm{m}^{-3}$.

Since investigations were first begun in this area (1958) 2 groups, Medusae and Siphonophora, have been studied together and will be referred to as Medusae/Siphonophora in this paper.

Bacteria: During the study period samples were collected on a monthly basis at $0,10,20,30,50,75$ and $100 \mathrm{~m}$ depths. Samples were processed at sea immediately after sampling. Mean values integrated for the entire water column were used as input data for the analysis of time series. A spreading technique on solid ZoBell's medium (ZoBell 1946) was used in 2 replications. The number of heterotrophic bacteria was expressed as CFU ml ${ }^{-1}$ (colony forming units) after $7 \mathrm{~d}$ incubation at $20^{\circ} \mathrm{C}$.

Methods of sample collection, preparation of media, plating out and incubation remained unchanged over the $21 \mathrm{yr}$ period of measurements in order to continue the series of available data. Since 1980 , parallel observation of total bacteria counts using epifluorescence microscopy (Hobbie et al. 1977) was conducted to check the validity of the data. A significant correlation between the number of heterotrophic bacteria and total bacterial count was obtained (Šolić \& Krstulović 1991a). It was also found that heterotrophic bacteria respond well to the envi-

Fig. 1. (A) Long-term fluctuations ( $\longrightarrow$ ) in the abundance of zooplankton groups (standardized annual means from 1960 to 1982) and bacteria (standardized annual means from 1968 to 1988). Fitted second-order polynomials are superimposed (- - ). (B) Time series consisting of monthly values detrended for seasonal patterns 
ronmental changes and are in good correlation with a series of other biotic and abiotic factors (Krstulović \& Śolić 1990, Śolić \& Krstulović 1991a, b).

Data analysis. Diversity was calculated as the Shannon-Weaver diversity index $\left(H^{\prime}\right)$, using logarithms to the base ' $e$ ' in the calculations (Shannon \& Weaver 1947):

$$
H^{\prime}=-\sum_{j=1}^{\mathrm{n}} P_{i}\left(\log P_{i}\right),
$$

where $P_{i}=\mathrm{n}_{i} / \mathrm{N}_{i} ; \mathrm{n}_{1}=$ the no. of individuals of a particular group; and $N_{i}=$ total no. of individuals.

Two multivariate techniques, Principal Component Analysis (PCA) and Multidimensional Scaling (MDS) ordination, were also used in data analysis.

Ordination of samples by PCA is a technique for mapping the samples in a low number of dimensions (usually 2) such that the distance between samples attempts to reflect (d.s)similarity in community structure (Harris 1975, Pimentel 1979, Chatfield \& Collins 1980, Seber 1984, Clarke \& Green 1988). In our study PCA was used to extract the main patterns of year-toyear changes in abundance, and PCA ordination, based on a correlation matrix, was used to detect similarity between fluctuations of bacteria and individual zooplankton groups.

MDS (Kruskal \& Wish 1978) is a nonparametric method which uses the rank order of similarities between samples rather than their absolute values. It has several conceptual advantages over other methods (Clarke \& Green 1988) and has been shown empirically to be very robust for analyzing planktonic data. The ordination procedure results in a scatter plot in which each replicate sample is represented by a point, the distances between points following the same rank order as the pairwise dissimilarities in species composition between samples. The extent to which this ideal is realized, in a 2-dimensional plot for example, is indicated by a 'stress' coefficient. In our study MDS ordination was used for discrimination between years according to both zooplankton abundance and percentage presence of individual zooplankton groups. MDS ordination is based on the Bray-Curtis similarity matrix (Bray-Curtis 1957).

Spectral analysis was applied to establish periodicities of cyclical oscillations of studied groups.

\section{RESULTS}

\section{Time series}

Fluctuations in the abundance of zooplankton groups for the period 1960-1982 and bacteria for 1968-1988 are shown in Fig. 1. Annual means of abundance were standardized to zero mean and unit variance, and fitted second-order polynomial curves were superimposed to emphasize long-term trends (Fig. 1A). Time series consisting of monthly values detrended for seasonal patterns are also shown (Fig. 1B). Comparison shows that there is no essential difference between the time series of monthly data detrended for seasonal patterns and the annual mean series. No regular pattern of fluctuations, common to all the groups, was recorded, even though some groups showed similarity in temporal distribution. An upward trend spanning the whole period was established for Copepoda, Cladocera, Thaliacea and bacteria. A downward trend was established for Decapoda and Chaetognatha. All established trends are statistically different from zero $(p<0.01)$. Maxima of abundance were found for most of the groups in the years 1975 and 1980, and minima in 1971, 1977, 1981 and 1982. Similar oscillation periods in individual groups were observed by spectral analysis of detrended time series (Table 1)

Table 1 Oscillation periods of zooplankion yroups and bacteria obtained by spectral analysis based on full data set detrended for seasonal patterns

\begin{tabular}{lllll|}
\hline Group & \multicolumn{3}{c}{ Period (yr) } \\
\hline Copepoda & 7.3 & & 3.7 & \\
Appendicularia & 7.3 & & & 2.4 \\
Cladocera & 7.3 & & 2.4 \\
Medusae/Siphonophora & & 5.5 & 2.4 \\
Chaetognatha & & 5.5 & 2.6 \\
Thaliacea & & 5.1 & 2.6 \\
Mollusca & & & 3.7 & 2.2 \\
Decapoda & 7.3 & & & 2.2 \\
Polychaeta & 7.3 & & \\
Bacteria & 11.8 & & 5.1 & 2.7 \\
\hline
\end{tabular}

\section{Multivariate analysis of time series}

PCA was carried out on an array consisting of the data set for all zooplankton groups for each year. Fig. 2 shows the first (PC1) and second (PC2) principal component which account for $69 \%$ of the variability. PC1 explains $43 \%$ of variability and can be regarded as the best possible single representation of the annual fluctuations in abundance for all the zooplankton groups. All PC1 weight values are positive (Fig. 2C) suggesting that $\mathrm{PCl}$ represents a pattern of variation more or less common to all groups. This pattern of fluctuation is characterized by maximal values in the years 1975 and 1980 and by minimal values in 1971, 1977. 1981 and 1982. High positive values of PC1 weight were found for Appendicularia, Med- 

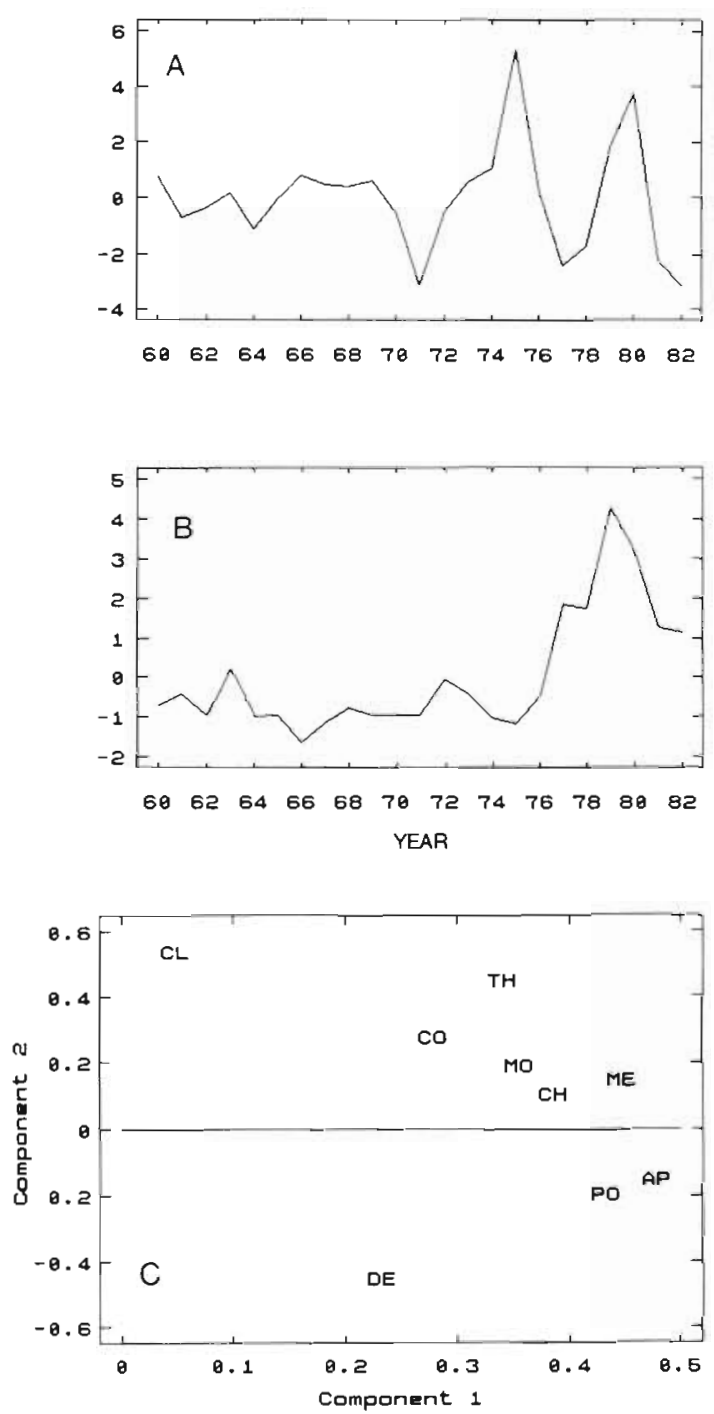

Fig. 2. Principal Component Analysis (PCA) of standardized (zero mean, unit variance) zooplankton data. (A) First principal component (PC1) (43\% of the variability); (B) second principal component (PC2) (26\% of the variability); (C) first 2 component weights. CO: Copepoda; AP: Appendicularia; CL: Cladocera; ME: Medusae/Siphonophora ${ }_{i} \mathrm{CH}$ : Chaetognatha; TH: Thaliacea; MO: Mollusca; DE: Decapoda; PO: Polychaeta

usae/Siphonophora, Polychaeta and Chaetognatha; these zooplankton groups are best characterized by PC1.

PC2 explains $26 \%$ of variability, representing a long-term trend of increase which occurs in the time series of some zooplankton groups. Year-to-year fluctuations of Cladocera, Thaliacea and Copepoda are well described by PC2 (Fig. 2C). The negative PC2 weight value of Decapoda is the result of a downward trend present in time.

\section{Discrimination between years}

MDS ordinations of the zooplankton abundance data using untransformed and double-square root transformed data are given in Fig 3. For the transformed data MDS configuration (Fig. 3A) shows a clear separation to the left of the years 1980,1979 and 1975, and to the right of the years 1971, 1977, 1981 and 1982. Groups separated to the left are those with higher abundance of most of the zooplankton groups whereas those separated to the right are those with minimal abundance. All other groups are clustered around the center.

Untransformed ordination shows similar although slightly less pronounced separation (Fig. 3B). The untransformed ordination has a horseshoe shape, and the gradient of abundance decrease starts from the left end over the top to the right end of the horseshoe.

Fig. 4 shows the MDS ordination of percentage presence of individual zooplankton groups. It is obvious that this ordination coincides with the MDS zooplankton abundance ordination to a considerable extent. That is, most of the years separated from the central group are at the same time the years of either maximal or minimal abundance. The years separated to the left of the central group $(1980,1979,1975,1978)$ are the
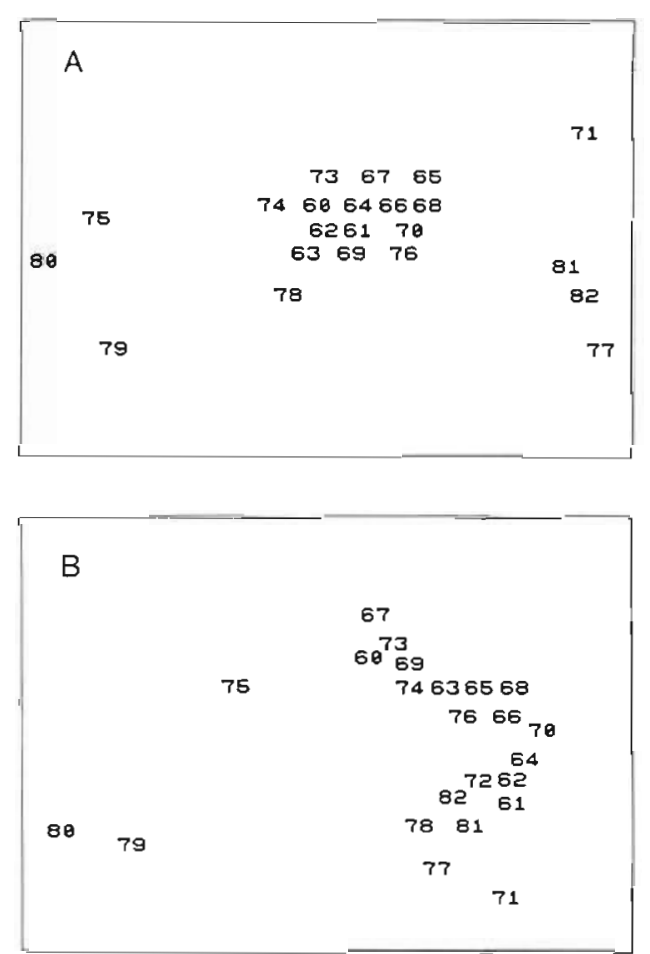

Fig. 3. Multidimensional Scaling (MDS) ordination for the 1960-1982 zooplankton abundance data. (A) Double-square root transformed data (stress $=0.048$ ); $(B)$ untransformed data (stress $=0.065$ ) 

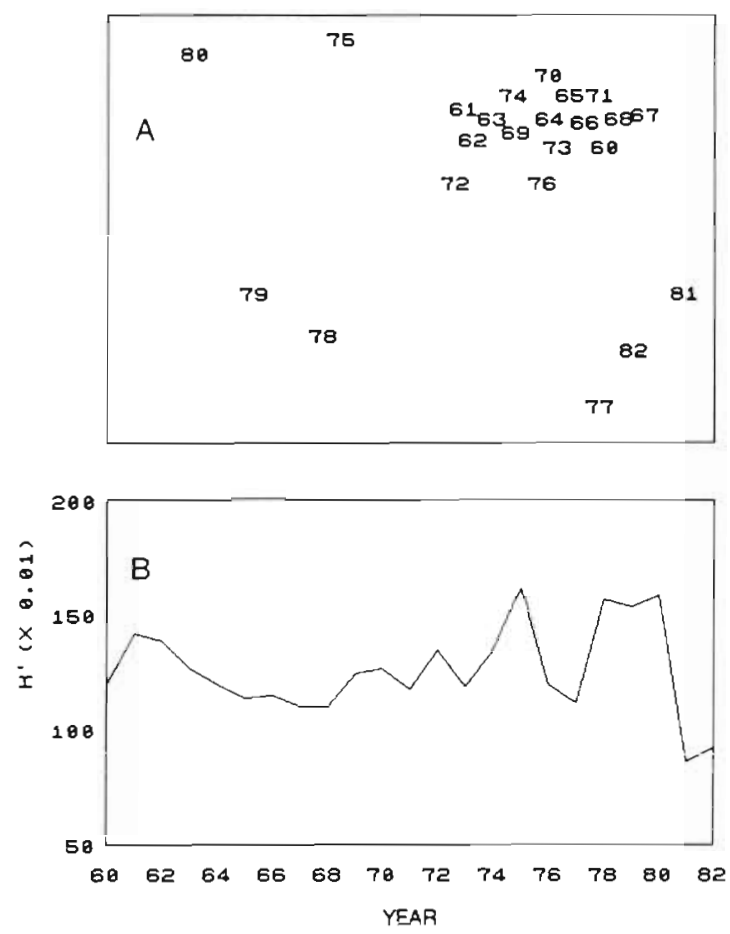

Fig. 4. (A) Multidimensional Scaling (MDS) ordination for the 1960-1982 data of zooplankton groups proportion (stress = 0.031); (B) fluctuation of the Shannon-Weaver diversity index $\left(H^{\prime}\right)$ through 1960-1982

years of maximal diversity index whereas the minimal diversity indices are characteristic of the years separated to the right and downward of the central group (1977, 1981, 1982) (Fig. 4B).

The years in which the percentage proportion of zooplankton groups showed rather considerable departure from the average presence for the entire period were analyzed through the relationships among 4 groups (Fig. 5). A negative relationship was recorded between the presence of Copepoda and Thaliacea. In the years 1975, 1979 and 1980 Copepoda showed a significant decline when Thaliacea increased. In contrast, in 1981 and 1982, Copepoda were markedly dominant whereas Thaliacea presence was almost negligible. In 1975 Appendicularia presence significantly increased, whereas a significant increase of Cladocera presence is a characteristic of the 1977-1979 period.

\section{Relation between zooplankton and bacteria fluctuations}

The relation between the time series of total zooplankton and bacteria abundance for the period 1968-1982 was also studied. The long-term trend com- ponent and residual periodical oscillation component were extracted from both time series (Fig. 6A, B). Fluctuations of total zooplankton and bacteria show a positive relationship in both components, the longterm increase trend being recorded for both, as well as cyclical oscillations with a period of $5.5 \mathrm{yr}$.

To establish the relationship between bacteria fluctuations and fluctuations of individual zooplankton groups PCA was used for 2 data sets. The first set consisted of fitted trend values, and the second of detrended time series values. A scatter diagram of the first 2 eigenvectors of the correlation matrix for the first data set is shown in Fig. 6C. It is quite clear that bacteria are grouped with the zooplankton groups in which an increasing trend was established (Cladocera, Thaliacea and Copepoda). Chaetognatha, Appendicularia, Decapoda and Polychaeta, for which a decreasing trend was found, are grouped to the left side of the first vector. Medusae/ Siphonophora and Mollusca, with no trend, are grouped centrally around the first vector.

The analysis of the second data set showed positive relationships between cyclical oscillations of bacteria and most of the zooplankton groups with the exception of Cladocera and Decapoda (Fig. 6D).

\section{Relation to the environment}

The relationship between zooplankton fluctuations and the fluctuations of sea-surface temperature, salinity and frequency of southerly weather type (SWT) was analyzed. Southerly weather type is characterized by

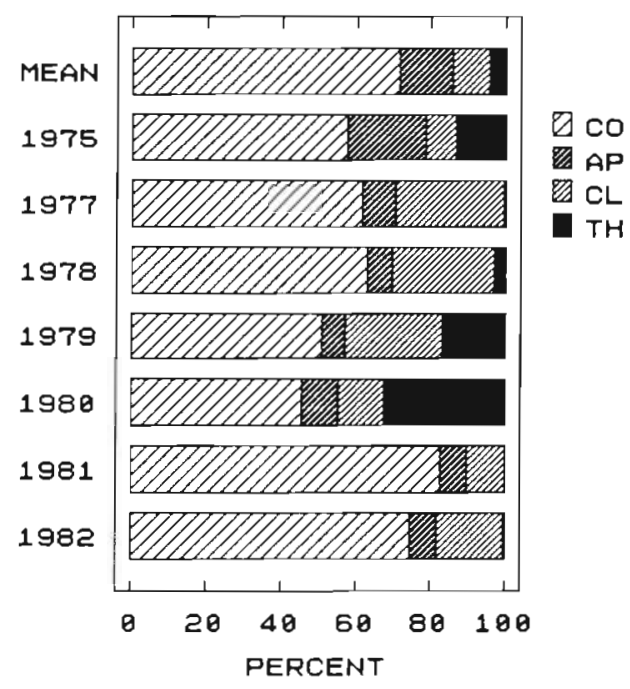

Fig. 5. Proportion of 4 zooplankton groups in the years which were separated in MDS ordination shown in Fig. $4 \mathrm{~A}$. CO: Copepoda; AP: Appendicularia; CL: Cladocera; TH: Thaliacea. MEAN: mean values for the period 1960-1982 

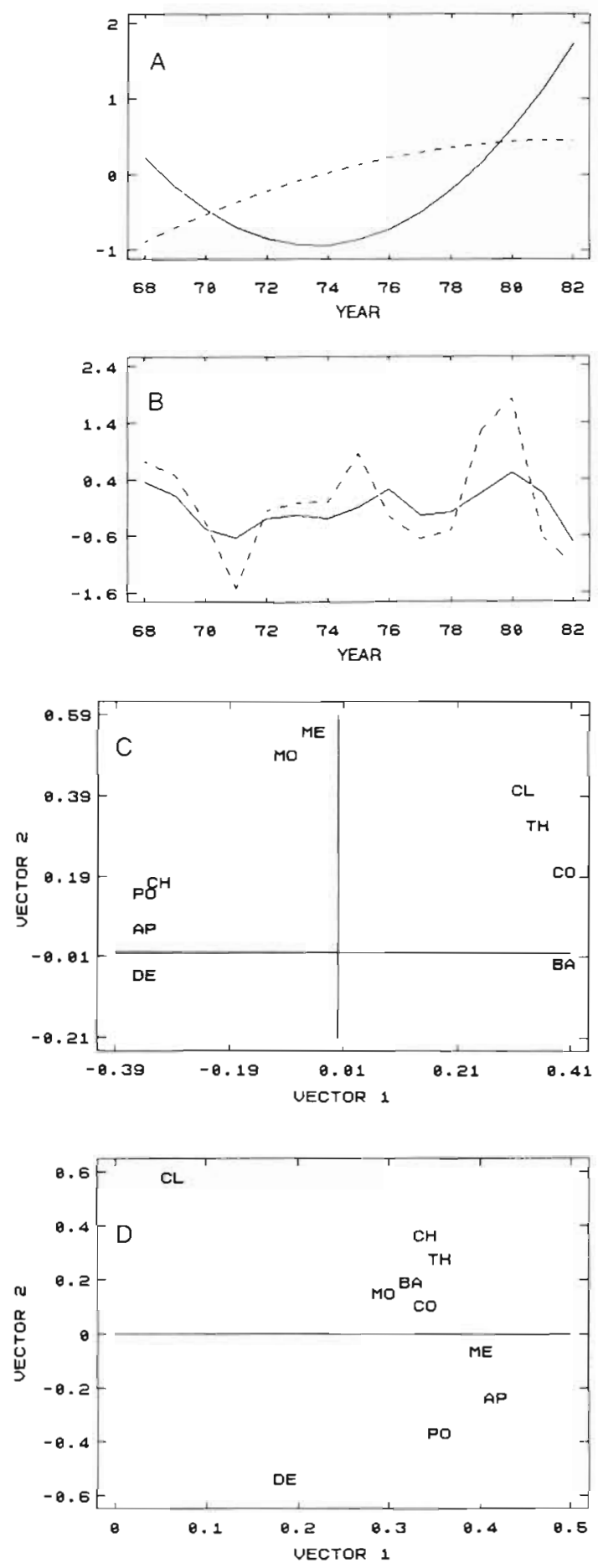

Fig. 6. Relation between the abundance fluctuations of bacteria (-) and total zooplankton (- - ) during 1968-1982 (zero mean, unit variance standardized data). (A) Trend components of abundance time series of bacteria and total zooplankton. (B) Residual components ( 5.5 yr periodicity was established by spectral analysis). (C) Scatter diagrams of the first 2 eigenvectors of the correlation matrix derived from fitted trend values shown in (A). (D) Scatter diagram of the first 2 eigenvectors of the correlation matrix derived from residual values shown in (B). Abbreviations as in Fig. 2 lower atmospheric pressure, southeasterly wind and a high amount of precipitation.

A significant relationship between year-to-year changes in frequency of SWT, salinity and PC1 of zooplankton abundance was found (Fig. 7). Common maxima were recorded in 1975 and 1980 and common minima in 1971 and 1977 (Fig. 7 A, B, C). Pronounced salinity maxima and frequency of SWT recorded in 1968-1969 were not associated with PC1 to that extent. Spectral analysis pointed to a $5.5 \mathrm{yr}$ periodicity as common to PC1 of zooplankton abundance and studied environmental factors (Fig. 7D, E, F).

Cyclical oscillations of detrended PC2 of zooplankton abundance were in phase with cyclical oscillations of temperature showing a 7.3 yr periodicity (Fig. 8). A pronounced maximum value in 1979 and minimum in 1975 were common to both time series.

The correlation between long-term fluctuations of individual zooplankton groups and temperature and SWT is presumably, at least partly, related to the timing of their seasonal cycles. The correlation with temperature was found for the zooplankton groups whose maxima occurred in the warmer part of the year (Fig. 9A). SWT is more frequent in the colder part of the year, so it was better correlated with the zooplankton groups whose abundance was maximal or significant during that time of the year (Fig. 9B).

\section{DISCUSSION}

The analyses of zooplankton and bacteria abundance fluctuations suggest 3 main patterns of their year-to-year fluctuations.

The dominant pattern has a form of cyclical oscillations with $5.5 \mathrm{yr}$ periodicity. This pattern is in good correlation with salinity and SWT. It presumably may be accounted for by ingression of Mediterranean water characterized by higher salinity and nutrient concentrations (Buljan 1953, Zore-Armanda 1969, 1974). Oscillations of a number of parameters (salinity, nutrients. bacteria, primary production, zooplankton and standing crop, fish catch) in the Adriatic were previously attributed to ingressions of Mediterranean water due to the penetration of cold and dry polar air and a higher air pressure gradient over the eastern Mediterranean (Buljan 1969, Vučetić \& Pucher-Petković 1969, PucherPetković et al. 1971, Karlovac 1973, Vučetić 1973, 1983. 1988, Karlovac et al. 1974, Vučetić \& Alegria-Hernandez 1986, Šolić \& Krstulović 1991a, b). Lower atmospheric pressure over the Adriatic, a characteristic of SWT, makes Mediterranean water ingression still easier. These studies indicated that the Mediterranean water ingressions are important regulators of primary and secondary production in the Adriatic. 

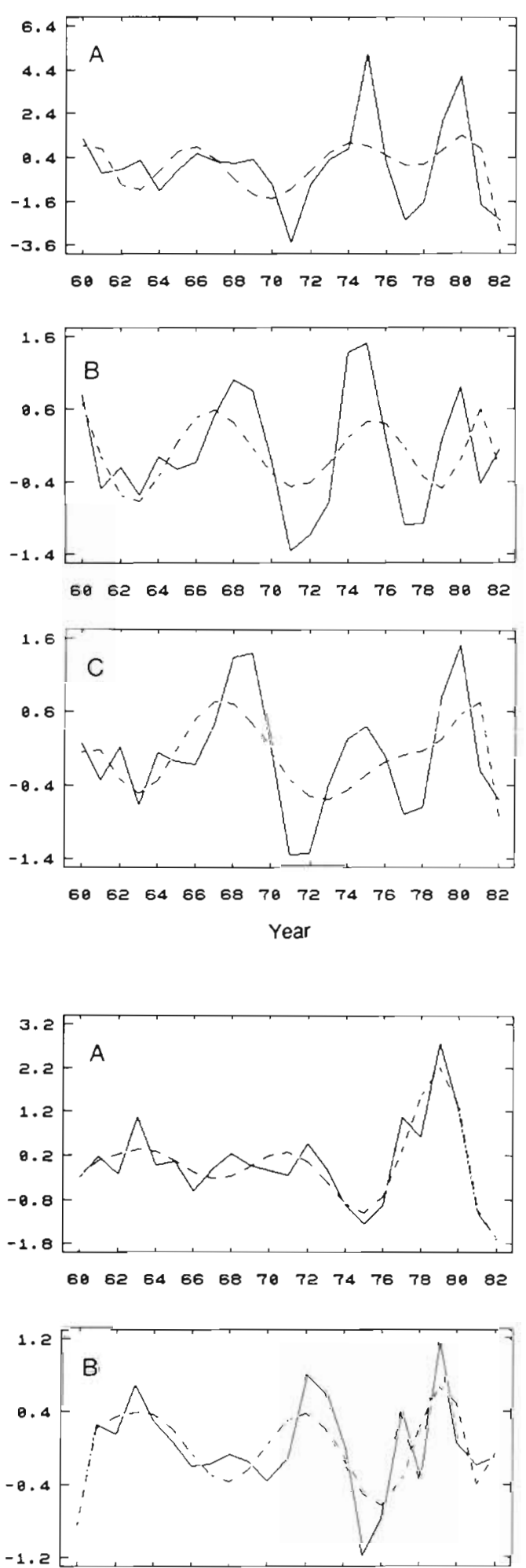

$\begin{array}{llllllllllll}68 & 62 & 64 & 66 & 68 & 78 & 72 & 74 & 76 & 78 & 88 & 82\end{array}$

Year
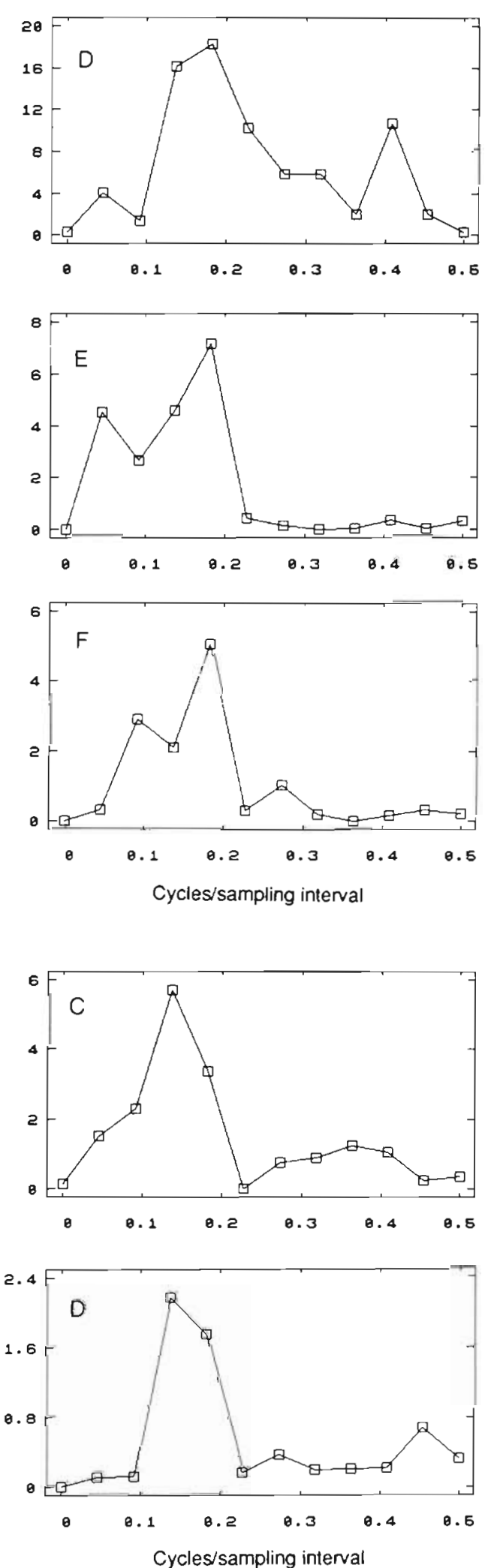

Fig. 7. (A) First principal component (PC1) of zooplankton abundance; (B) annual means of frequency of days of southerly weather type (SWT) (C) annual means of salinity. All graphs are standardized to zero mean and unit variance, and superimposed are fitted 6 th order polynomials $(---)$. Power spectra of (D) $P C 1 ;(E)$ frequency of days of SWT: ( $F$ ) salin. ity. The spectra are based on time series of 23 annual values (1960 -1982) and calculated with a maximal lag of $12 \mathrm{yr}$

Fig. 8. (A) Detrended second principal component (PC2) of zooplankton abundance. (B) Annual means of surface temperature. All graphs are standardized to zero mean and unit variance and superimposed are fitted 6th order polynomials (- - -). Power spectra of (C) detrended PC2 and (D) surface temperature. The spectra are based on time series of 23 annual values (1960-1982) and calculated with a maximum $\operatorname{lag}$ of $12 \mathrm{yr}$

Fig. 9. Seasonal variations in abundance of zooplankton groups (seasonal index for 1960-1982) and bacteria (seasonal index for 1968-1988) in relation to seasonal variations of (A) temperature and (B) southerly weather type (SWT) 
A

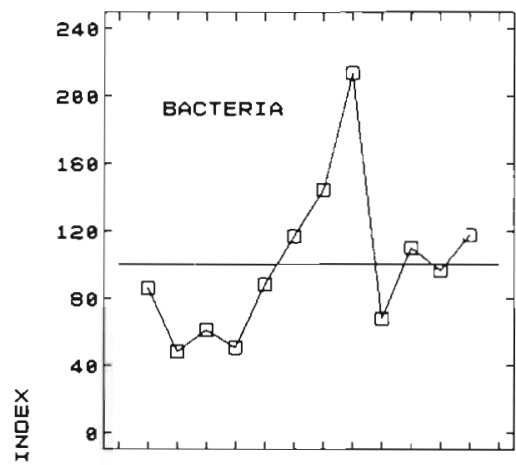

123456789181112

索

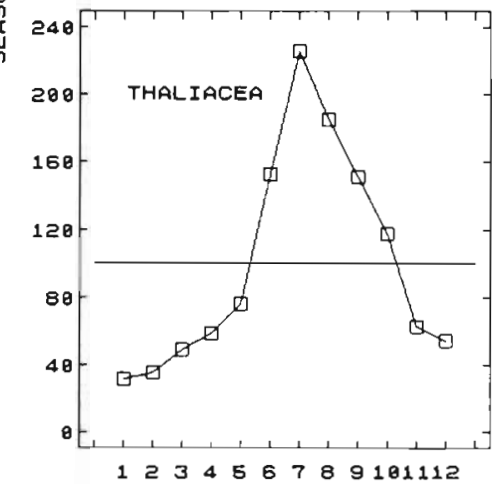

B

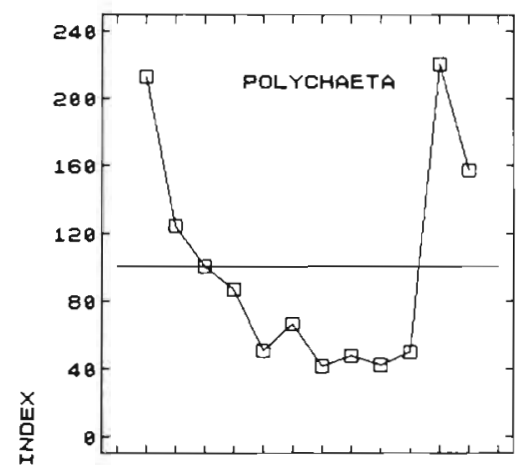

索

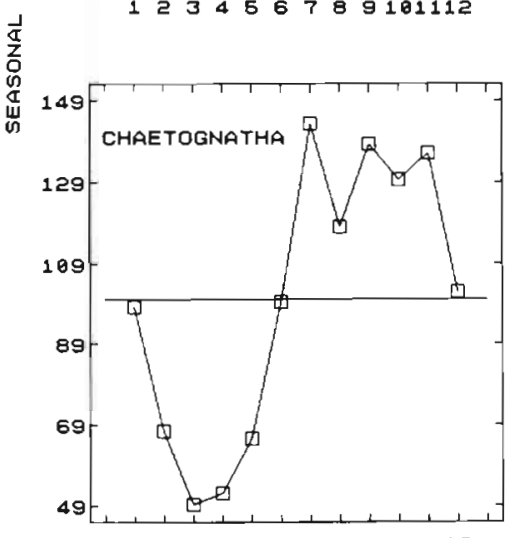

123456789181112

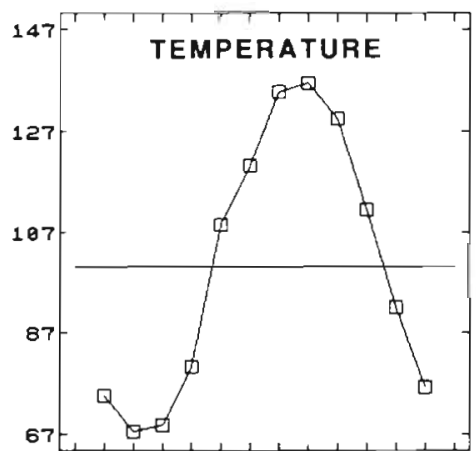

123456789181112
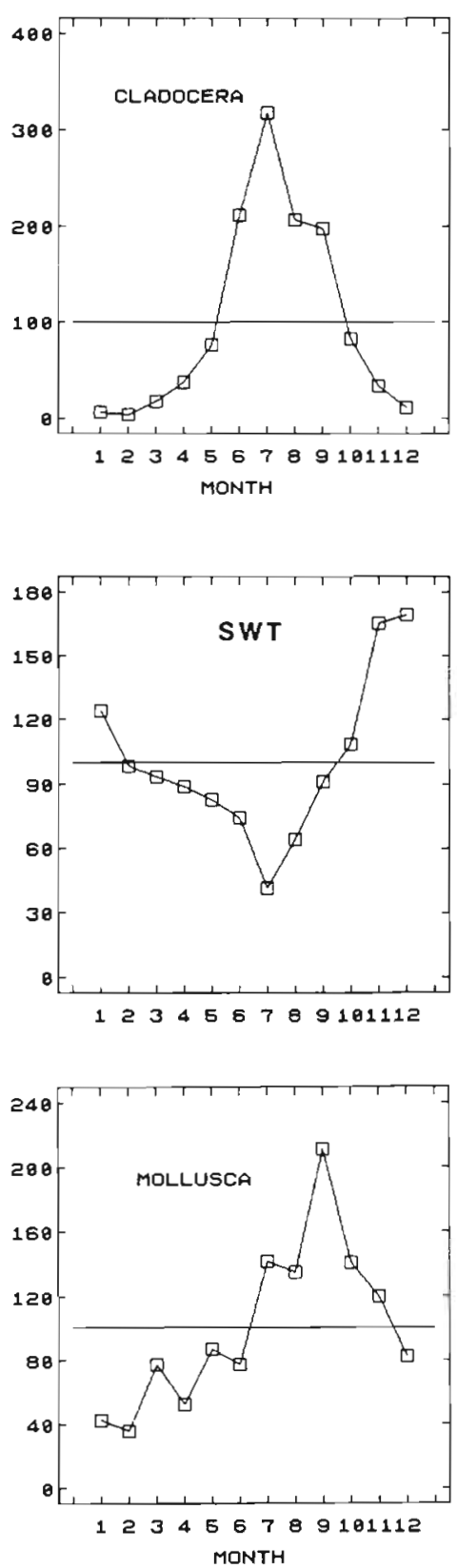

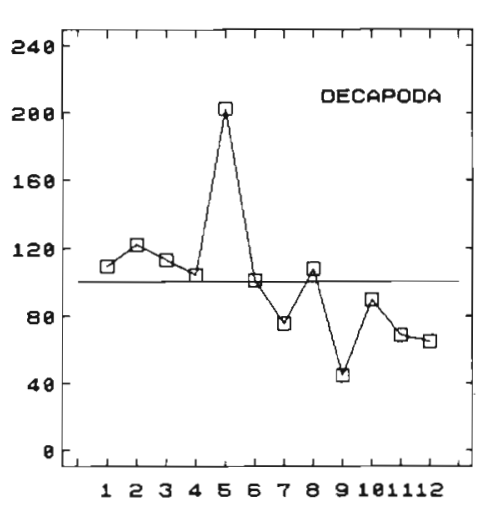

123456789181112
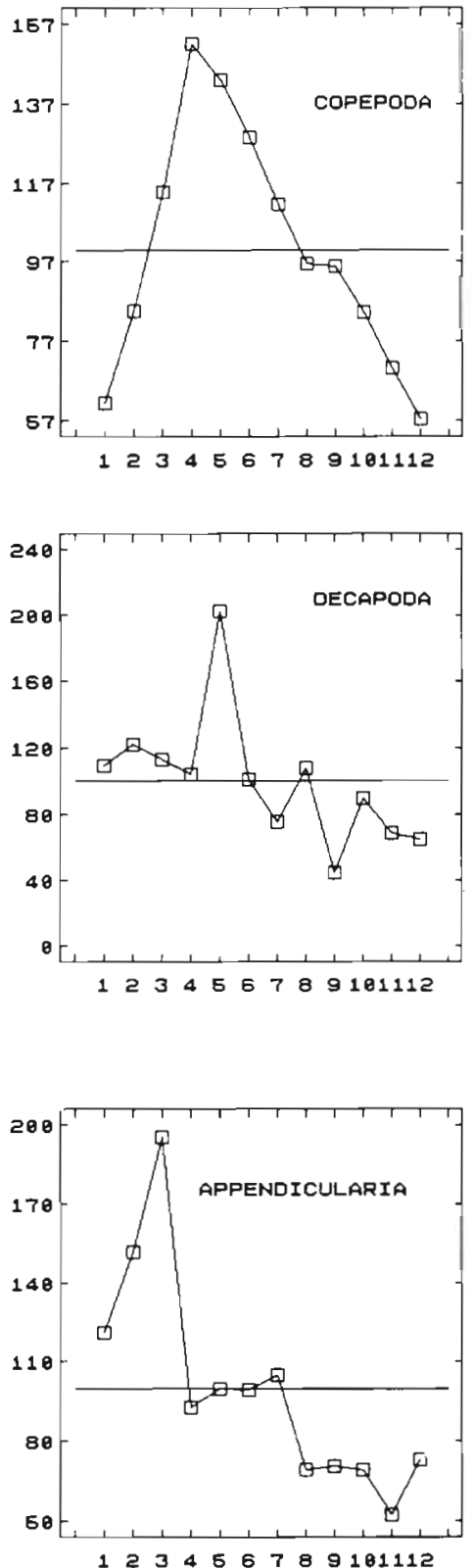

123456789101112

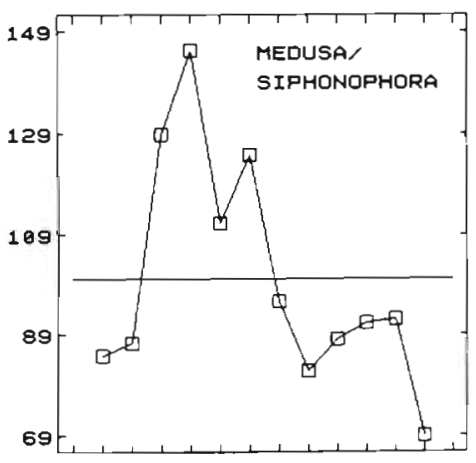

123456789101112 
The years $1967-1968$ are considered to be a period of rather marked ingression. Increases in salinity and nutrient levels were recorded from the Adriatic (ZoreArmanda et al. 1987) resulting in a maximal phyto. plankton population in 1968 (Pucher-Petković \& Marasović 1980) and maximal primary production in 1969 (Pucher-Petković et al. 1987). Maximal quantities of sardine eggs were also observed in 1968-69 and 1969-70 (Karlovac 1973). Next, a primary production maximum was reported for the year 1980 (PucherPetković et al. 1987). Maximal total bacterial counts were found in the same year, as well as maximal bacterioplankton production (Krstulović 1989).

Two pronounced maxima in the $21 \mathrm{yr}$ time series of heterotrophic bacteria density were recorded in 1968 and 1980 (Šolić \& Krstulović 1991a). The phenomenon of mass occurrence of the scyphomedusa Pelagia noctiluca in the Adriatic, beginning in 1977, was preceded by the abnormal presence of highly saline water in winter 1976, which is again indicative of stronger advection of the Mediterranean water into the Adriatic (Vučetić 1983, 1984, 1986).

Next in importance is that the pattern of fluctuations of zooplankton and bacteria abundance has the form of an increasing long-term trend. This may very likely be accounted for by eutrophication. The eutrophication, first identified in the coastal area, has extended towards the open Adriatic in the last decade. The results of eutrophication are increasing trends of primary production (Pucher-Petković \& Marasović 1988), numbers of some zooplankton species (Vučetić 1980), heterotrophic bacteria density (Šolić \& Krstulović 1991a, b), oxygen saturation in the surface layer (Zore-Armanda et al. 1987) and sardine and small pelagic fish catch (Alegria-Hernandez 1983), as well as decreasing trends of oxygen saturation in the near-bottom layer (Zore-Armanda et al. 1987), N/P ratio (Vukadin \& Stojanoski 1976, Viličić \& Stojanoski 1987) and sea water transparency measured by Secchi disc (ZoreArmanda et al. 1987).

Lastly, significant patterns of zooplankton and bacteria abundance fluctuations are cyclical oscillations with a 7.3 yr periodicity, positively correlated with temperature. This periodicity is very close and may be related to the oscillations of solar activity of which one of the most significant periodicities is about $8 \mathrm{yr}$ (Regner \& Gačić 1974, Solić \& Krstulović 1991a) In the Adriatic, 8 yr periodicities were previously reported for temperature, primary production, zooplankton abundance, different developmental stages of anchovy and sardine catch along the eastern Adriatic coast (Źupanović 1968, Regner \& Gačić 1974, Regner 1985).

In conclusion this paper shows that the fluctuations of zooplankton and bacteria in the Adriatic are due to the combined effects of a series of factors of which water exchange with the Mediterranean, climatic factors, particularly temperature and atmospheric pressure, and eutrophication are most important.

\section{LITERATURE CITED}

Alegria Hernandez, V. (1983). Assessment of pelagic fish abundance along the eastern Adriatic coast with special regard to sardine (Sardina pilchardus Walb.) population. Acta Adriat. 24: 55-95

Bray, J. R., Curtis, J. T. (1957). An ordination of the upland forest communities of southern Wisconsin. Ecol. Monogr. 27: $325-349$

Buljan, M. (1953). Fluctuations of salinity in the Adriatic. Izvješca-Reports Ribarstveno biološke ekspedicije 'Hvar' Institut za oceanografiju i ribarstvo, Split 2: 1-64

Buljan, M. (1969). Relation between some factors affecting productivity and fish catch in the central Adriatic area. Stud. Rev. gen. Fish. Coun. Mediterr. 41: 25-39

Büljañ, M., Zore-Armanda, M. (1956). Hydrographic data on the Adriatic Sea collected in the period from 1952 through 1964. Acta Adriat. 12: 1-438

Buljan, M., Zore-Armanda, M. (1979). Hydrographic properties of the Adriatic Sea in the period from 1965-1970. Acta Adriat. 20: 1-368

Chatfield, C., Collins, A. J. (1980). Introduction to multivariate analysis. Chapman and Hall, London

Clarke, K. R, Green, R. H. (1988). Statistical design and analysis for a 'biological effects' study. Mar. Ecol. Prog. Ser. 46: $213-226$

Harris, R. J. (1975). A primer of multivariate statistics. Academic Press, New York

Hobbie, J. E., Daley, J., Jasper, S. (1977). Use of nucleopore filters for counting bacteria by fluorescence microscopy. Appl. environ. Microbiol. 33: 1225-1228

Karlovac, J. (1973). Oscillations des quantités des stades planctoniques de la sardine, Sardina pilchardus Walb., dans l'Adriatique moyenne au cours des saisons de ponte de 1965/66 jusqu'à 1969/70. Rapp. Comm. int. Mer Médit. 21: 813-815

Karlovac, J., Pucher-Petković, T., Vučetić, T., Zore-Armanda, M. (1974). Procjena bioloških resursa Jadrana na osnovi planktona. Acta Adriat. 16: 157-184

Krstulović, N. (1989). Raspodjela i produkcija bakterioplanktona u obalnom i otvorenom dijelu srednjeg Jadrana. Ph.D. thesis, Univerzitet u Beogradu

Krstulović, N., Solić, M. (1990). Long-term study of heterotrophic bacteria as indicator of eutrophication of the open middle Adriatic Sea. Estuar. coast. Shelf Sci. 30: 611-617

Kruskal, J. B., Wish, M. (1978). Multidimensional scaling. Sage Publications, Beverly Hills, CA

Pimentel, R. A. (1979). Morphometrics: the multivariate analysis of biological data. Kendall/Hunt, Dubuque, IA

Pucher-Petković, T (1963). Rapports quantitatifs entre les divers groupes du phytoplancton en Adriatique moyenne. Rapp. Comm. int. Mer Médit. 17: 479-485

Pucher-Petković, T. (1966). Végétation des diatomees pélagiques de l'Adriatique moyenne. Acta Adriat. 13: 1-97

Pucher-Petković, T. (1968). Fluctuations pluriannuelles du phytoplancton en relation avec certains facteurs méteorologiques et hydrographiques. Rapp. Comm. int. Mer Médit. 19: 399-401

Pucher-Petković, T. (1971). Recherches sur la production primaire et la densite des populations du phytoplancton en 
Adriatique moyenne (1962-1967). Rapp. Comm. int. Mer Médit. 20: 339-343

Pucher-Petković, T., Marasović, I. (1980). Developpement des populations phytoplanctoniques caracteristiques pour un milieu eutrophise (Baie de Kaštela, Adriatique centrale). Acta Adriat. 21: 79-94

Pucher-Petković, T., Marasović, I. (1988). Indications d'eutrophisation des eaux du large de l'Adriatique centrale Rapp. Comm. int. Mer Médit. 31: 226

Pucher-Petković, T., Zore-Armanda, M., Kačić, I. (1971) Primary and secondary production of the middle Adriatic in relation to climatic factors. Thalassia jugosl. 7: 301-311

Pucher-Petković, T., Marasović, I., Vukadin, I., Stojanoski, L. (1987). Time series of productivity parameters indicating eutrophication in the middle Adriatic waters. Fifth. Technical Consultation on stock assessment in the Adriatic, General Fisheries Council for the Mediterranean, Bari, p. 41-50

Regner, S. (1985). Ecology of planktonic stages of the anchovy, Engraulis encrasicholus (Linnaeus, 1758), in the central Adriatic. Acta Adriat. 26: 1-113

Regner, S., Gačić, M. (1974). The fluctuations of sardine catch along the eastern Adriatic coast and solar activity. Acta Adriat. 15: 1-15

Seber, G. A. F. (1984). Multivariate observations. Wiley, New York

Shannon, C. E., Weaver, W. (1947). The mathematical theory of communication. Univ. Illinois Press, Urbana

Šolić, M., Krstulović, N. (1991a). Time series of heterotrophic bacteria density in the central Adriatic Sea. Cont. Shelf Res. 11. 397-407

Šolić, M., Krstulović, N. (1991b). Distribution of heterotrophic bacteria as affected by eutrophication and fluctuations of environmental factors. Kieler Meeresforsch., Sonderh. 8: $59-65$

Viličić, D., Stojanoski, L. (1987). Phytoplankton response to concentration of nutrients in the central and southern Adriatic Sea. Acta Adriat. 23: 73-84

Vučetić, $T$ (1971a). Long-term zooplankton standing crop fluctuations in the central Adriatic coastal region. Thalassia jugosl. 7: 419-428

Vučetić, T. (1971b). Fluctuations à long terme du macrozooplancton dans l'Adriatique centrale: oeufs de Sardina pilchardus Walb., d'Engraulis encrasicholus L. et larves de differentes poissons. Arch. Oceanogr. Limnol. 17: 141-156

Vučetić, T. (1973). Zooplankton and the circulation pattern of the water masses in the Adriatic. Neth. J. Sea Res. 7: $112-121$

Vučetić, T. (1975). Synchronism of the spawning season of some pelagic fishes (sardine,anchovy) and the timing of the maximal food (zooplankton) production in the Central Adriatic. Publ. Staz. Zool. Napoli 39 (suppl.): 347-365

This article was submitted to the editor
Vučetić, T. (1977). Les investigations ecologiques a long terme du zooplancton et leur application aux problemes de la pollution. Rapp. Comm. int. Mer Médit. 24: 109-111

Vučetić, T (1980). Some species of plankton as indicators of neritisation (eutrophication) of the Eastern Central Adriatic. Ves Journées Etud. Pollutions, Cagliari, Comission Internationale pour l'exploration Scientifique de la Mer Mediterranee, p. 769-770

Vucetić, T. (1983). Fluctuation in the distribution of the scyphomedusa Pelagia noctiluca (Forskal) in the Adriatic. In: Boutler, J. (ed.) Proc. 17th European Marine Biology Symposium. Oceanol. Acta, vol. spéc.: 207-211

Vučetić, T. (1984). Some causes of the blooms and unusual distribution of the jellyfish Pelagia noctiluca in the Mediterranean (Adriatic). In: Workshop on jellyfish blooms in the Mediterranean, Athens, Greece, 31 Oct.4 Nov. 1983. UNEP/WG 118/Inf. 3: 167-176

Vučetić, T. (1986). Reproduction and distribution of Pelagia noctiluca and changes in environmental conditions in the Adriatic. Nova Thalassia 8 (suppl. 2): 93-98

Vučetić, T. (1988). Studies of the Adriatic biological resources. Long-term (1960-83) fluctuations of zooplankton biomass in the Palagruža-Gargano area. FAO Fish. Rep. 394: $63-70$

Vučetić, T., Alegria-Hernandez, V. (1986). Long-term fluctuations of predator fish and prey plankton jellyfish Pelagia noctiluca in the Mediterranean (Adriatic). Rapp. Comm. int. Mer Médit. 30: 230

Vućetić, T., Pucher-Petković, T. (1969). Long term observation of plankton fluctuation in the Central Adriatic. Stud. Rev. gen. Fish. Coun. Mediterr. 41:13-23

Vukadin, I. Stojanoski, L. (1976). C:N:S:P ratio in the waters of the Middle and South Adriatic. Rapp. Comm. int. Mer Médit. 23: 41-43

ZoBell, C. E. (1946). Marine microbiology. Chronica Botanica Company, Waltham, MA

Zore-Armanda, M. (1969). Water exchange between the Adriatic and the Eastern Mediterranean. Deep Sea Res 16: $171-178$

Zore-Armanda, M. (1974). Formation of Eastern Mediterranean deep water in the Adriatic. Colloques int. Cent. natn. Rech. scient. 215: 127-133

Zore-Armanda, M., Stojanoski, L., Vukadin, I. (1987). Time series of oceanographic parameters: eutrophication of the open Adriatic waters. Fifth Technical Consultation on stock assessment in the Adriatic. General Fisheries Council for the Mediterranean, Bari, p. 71-77

Županović, $\breve{S}$. (1968). O uzrocima fluktuacije u lovinama srdele na istočnoj obali Jadrana. Anali Jadranskog Instituta, Jugoslavenska akademija znanosti i umjetnosti 4: $401-491$

Manuscript first received: May 14, 1992

Revised version accepted: December 4, 1992 